\title{
How to Connect Characteristics of the Future Career of Arts Students with College English Course?
}

\author{
Min Deng \\ College of Foreign Language Educatioion of China \\ West Normal University, \\ Nanchong, Sichuan, China \\ Stepbystep54@163.com
}

\begin{abstract}
As a special group of university students, Arts students face different careers after graduation and many of them will become actors, actresses, artists, singers and dancers, etc. However, the college English course is designed and practiced by a large number of common students, thus can't satisfy the special needs of many Arts students. This paper suggests that a specified and professional college English course model should be built and developed to meet the special needs of Arts students, thus make a great addition to English Teaching Reform.
\end{abstract}

Keywords-Arts Students, the development of career, College English

\section{INTRODUCTION}

At the beginning, it should be pointed out "art students" referred in this paper is a term that means professional arts, music and physical education students in colleges or universities instead of the traditional meaning of general arts students. According to the 2007 edition general office of the Ministry of Education issued "requirements" in College English Teaching in Colleges and universities, as a compulsory course for College English is to cultivate students' comprehensive ability of using English, especially listening and speaking ability [1] , so that they can use English to communicate effectively in the future study, work and social activities, while enhancing their self-learning ability, improve comprehensive cultural literacy, in order to adapt to the needs of China's social development and international exchanges [2] The teaching goal is not only suitable for college students of Arts and Science, but also suitable for art college students. They have the characteristics of learning and career development that are different from those of ordinary college students. First of all, art college students shoulder the spread of the national culture and arts and sports, have more opportunities to participate in social practice and performing exchange activities abroad and they also shoulder the responsibility of basic education of arts as well as sports in China. Secondly, the English learning foundation of Arts students is comparatively weak. There lays in great individual differences and most of the students are lack of enthusiasm for learning English. Finally, Arts students intend to be more active and outgoing with unique personality characteristics in personalities. According to the above characteristics, we, the teaching faculty should encourage the use of personalized English teaching model and College English course applied in Arts students' curriculum, suitable for the development of their future occupation.

\section{ARts StUdents’ Professional EdUCATION}

The policy of college enrollment expansion which started in 1999 has opened the process of the popularization of higher education in China. The scale of college graduates is becoming larger and larger, and the pressure on employment is becoming more and more prominent. The expansion of enrollment has broken the traditional enrollment mode of planned economy, and brought new challenges to education: how should the quality of higher education be closely integrated with social development and social needs?

As members of the massive job hunters, art and physical education students are still facing the grim situation of employment and occupation challenges. At present, in our example, students of Arts can be roughly divided into the arts and sports, the arts students including music, dance, arts majors.

From the employment data of nearly three grades of graduates, from Grade 2010 - Grade 2012 Arts graduates employment rate reached more than $92 \%$, among them, some are into the formal education system such as universities, schools at all levels, the cultural administrative departments or institutions, the work of education and training institutions is the main stream of employment, various types of enterprises accounted for about $1 / 3$ of the candidates [3]. At the same time, according to the data from Dai education school, Chengdu senior high school, which show that Arts students employment situation, analysis the need for graduates major in applied art market grow in demand, especially in animation production, product packaging, which are in emerging industries demand; while the traditional Arts graduate employment falls in its relatively narrow channels, so many students choose the education industry in the direction of the training to become a full-time art or sports teacher 
III. ARts College Students Occupation Development of ENGLISH CURRICULUM MODEL

\section{A. The Current Situation of English Learning of Arts Students}

The Arts college students who participated in College Entrance Examination must have excellent professional skills, however, the cultural lessons score only needs as 2/3 as other College students [4]. Arts students are lack of interest and enthusiasm in English learning. For them, English is not as important as their majors so the outcome is their English level is worse than other students, generally. While they taking the course of College English, classroom silence phenomena are frequent, and their attitudes towards English learning are more negative.

\section{B. Countermeasures for Improving the Efficiency of Arts Students 'English Course}

In English class, most of the Arts students hold negative attitudes towards participating in classroom activities. They ignore the instructions of teachers by silence objection. Most English class room of Arts students are occupied with chatting, eating, playing mobile phone, thus affecting the classroom order. [5]In a word, they are in a passive position in English learning, and they are accustomed to the traditional teacher centered teaching model and resist the model in the subconscious.

Solutions to these negative phenomena are the following:

Firstly, teachers should take individual conversations with those who encounter big challenges in either English or general study. Teachers speak the truth, give example, invite outstanding Arts graduates do lectures to motivate their learning interests, make it clear those university stages of learning, especially the importance of learning English, and the favorable conditions for its qualified English level occupation development.

Secondly, the English teaching for Arts students should emphasize in a solid foundation of English knowledge. If necessary, teachers should teach the ABCs (basic knowledge) to build a step-by-step comprehension of English language and also show them different English learning methods and illustrate how to apply these methods in details; increasing the amount of language input, like listening English pop songs and watch English country TV episodes, etc.

Thirdly, to teach the students with the characteristics of professional education, teaching materials should include English songs for the music majors, necessary international communication skills, the oral English for public welfare activities, art show, and international competitions in Foreign Affairs for students major in music, drawing, dancing, sports, and all sorts of Arts. English terms which are basic for related arts teaching are necessary in Arts students who will become Arts teachers. Choosing the appropriate and tightly-related teaching materials will not only stimulate the implementation of English learning interest but put English in a practical position which account for the future career of these Arts students professionally [6].

Finally, teachers should pay attention to strengthen the communication between teachers and students and treat them with real feelings, take the initiative to care about the students' learning and life. These emotional bonds will make students infected by the friendly and harmonious teacher-student relationship and relaxed classroom atmosphere, they are easily to be motivated by teachers' personalities and become an English lover.

\section{Specific Glossary Learning for Arts Students}

Due to the specialties of the majors, the English learning of art students should be fully integrated with their needs for job hunting and future work. Appropriate professional vocabulary in College English, in order to improve their ability of international academic exchanges to keep them in their professional field with international standards, Arts students need read English literature related to their majors, and can also communicate with the same major foreign peers, teachers and practitioners in a positive, active and efficient way. They need apply the specific vocabulary in understanding and promoting their newest and professional industry trends. As it is more detailed, students of painting and drawing need to be instructed to understand some of these professional words: figure painting, character sketch, Chinese ink painting, lithograph and so on; students of music need to know the specific words as jazz music, composition, andantino, duets, assai and so on; students of dancing need to know solo dance, lyric dance etc.

\section{Process Assessment for Arts Students}

Evaluation is an indispensable part of teaching. Frederich Taylor [7] put forward the concept of teaching evaluation, which emphasizes the significance of the examination, and the purpose is to understand the degree of students' learning progress. For a long time, we focus on the evaluation of students at the end of a semester or a learning stage according to an only evaluation standard--- the students' learning achievement to provide identification evaluation for students at this stage of learning; the summative assessment is so far from the real objective way of students' achievements assessments. Students' learning process is not only an important factor in determining the results of the study, but also an important content of the learning results. The evaluation of students' study is not only the evaluation of the final results of the learning, but also the evaluation of the way and process of learning.

For the Art Students, the educator should pay more attention on their interests, studying motivation and the way of study instead of the results of study only.

Then what should we do to find a more appropriate and objective way, which is also the most inspiring and motivating one for Arts students' English leaning ? The followings are some advice:

Firstly, focus on learning process. Arts Students will take different ways of learning in the process of learning, and different ways of learning will lead to different learning results. The evaluation method and evaluation of existing tools, evaluation and measurement do focus more on the surface learning type. However, deep learning types, like studying interest, studying method and studying motivation are more 
fundamental m which are lack of educators' attention. Too much attention on the studying results would mislead the students as well as educators, which causes students to learn by using the surface or achievement style learning [8].

Secondly, by using the methods of student self-evaluation and mutual evaluation in process evaluation, students can gradually grasp the correct way of learning, set up the right learning motivation and master their own learning strategies, so as to really improve the quality and effect of learning. This way can help students form a positive interaction of "deep learning, a high-level learning result, a deep learning style".

The last but not the least, process evaluation put the vision of evaluation in the field of student's whole learning experience, and believed that all valuable learning outcomes should be evaluated positively, regardless of whether these learning outcomes were within the intended target area. The result is that the students' enthusiasm for learning has been greatly improved and the richness of the learning experience is greatly enhanced. This is the ultimate goal that modern teaching expects [9].

\section{CONCLUSION}

With the rapid development of China's economy, the construction of cultural and artistic career, foreign Economic and cultural exchanges activities gradually strengthened, qualified students of Arts are not only proficient in professional skills, which cannot meet the needs of the talent market. Comprehensive talents are good at professional skills and English to meet growing demand. How to combine English Instruction with the ability of learning English and art level of college students and how to improve the English professional level should arouse the attention of the academia.

\section{ACKNOWLEDGEMENT}

The paper was supported by Funded projects: 2015 Si Chuan Province Humanities and Social Science Base--- Si Chuan Foreign Languages and Linguistics Research Center fund project number. (No. SCWYH15-13).

\section{REFERENCES}

[1] Higher Education Department of the Ministry of education. Teaching Requirements for College English Course [Z]. Beijing: Foreign Language Teaching and Research Press, 2007

[2] National Education Development Research Center.2000 China Education Green Book [M]. Beijing: Education Science Press, 2000

[3] Wang Hua, Fu Chang Hong. A Summary of the Application of Formative Assessment in Foreign Language Teaching [J]. Foreign Language Circles, 2006, (4)

[4] Huang Yuyun, et al. Vocational and Technical Education in China[M]. Chengdu, China: University of Electronic Science and Technology Press, 2004.

[5] Yu Yonghong, Li Zhi. Study on the Characteristics and Educational Countermeasures of contemporary college students' occupational values [J]. Education Exploration, 2003 (12).

[6] Qin Hongrui, wait. Talk about the professional development trend of College English Teaching [J]. Modern Economic Information, 2009, (20): 301.

[7] Frederich Taylor, The Principles of Scientific Management, [M]. New York and London, Harper \& brothers, 1911.

[8] Liuheng, Zhen Zhinian, Study on English Listening Classroom Teaching of Higher Vocat ional Students' negotiating [J], Journal of Jixi University, 20 08(5): 8 .

[9] Dingfang Su, Comprehensive curriculum objectives and quality of English Majors -- a review of the third foreign language teaching competition held by the foreign teachers' Association Cup in China[J],Foreign Language World.2013.(2) 43-49. 